\title{
The influence of French fries processing on the glycoalkaloid content in coloured-fleshed potatoes
}

\author{
Agnieszka Tajner-Czopek • Elżbieta Rytel • \\ Magda Aniołowska $\cdot$ Karel Hamouz
}

Received: 6 October 2013 / Revised: 8 January 2014 / Accepted: 10 January 2014 / Published online: 4 February 2014

(C) The Author(s) 2014. This article is published with open access at Springerlink.com

\begin{abstract}
French fries made from coloured-fleshed potatoes may be interesting alternative to the traditional snacks for consumers. However, potatoes contain glycoalkaloids (TGA), so potato tubers and obtained fried snacks should be subjected to comprehensive examination. The aim of this study was to determine the effect of different stages of French fries processing on the content of TGA ( $\alpha$-solanine and $\alpha$-chaconine) in the red- and blue-fleshed potatoes, in semi-products and ready-to-eat products. It was stated that during the processing of French fries prepared from coloured-flesh potato varieties significantly decreased the content of TGA ( $\alpha$-solanine and $\alpha$-chaconine) in the samples obtained at different stages of the process compared to the raw material. Potatoes with blue-fleshed of Vitelotte variety and red-fleshed of Highland Burgundy Red variety can be used to French fries processing due to their low content of TGA (in unpeeled and peeled potatoes). However, Blue Congo variety with blue-fleshed should not be applied to French fries processing, because of high TGA content in raw material and first of all in peeled potatoes flesh. The peeling process of coloured-fleshed potatoes decreased in TGA content on average by about $50 \%$, cutting process on average by about $53 \%$, whereas blanching on average by about $58 \%$ compared with the raw material. The highest decrease in TGA content was caused by frying process.
\end{abstract}

\footnotetext{
A. Tajner-Czopek $(\bowtie) \cdot$ E. Rytel $\cdot$ M. Aniołowska Department of Food Storage and Technology, Faculty of Food Science, Wrocław University of Environmental and Life Sciences, Chełmońskiego 37/41 Street, 51-500 Wrocław, Poland e-mail: Agnieszka.Tajner-Czopek@wnoz.up.wroc.pl; Agnieszka.Tajner-Czopek@up.wroc.pl

K. Hamouz

Department of Plant Production, Czech University of Life Sciences in Prague, 16521 Suchdol, Praha 6, Czech Republic
}

The mean values were about $97.5 \%$ in ready-to-eat French fries. In French fries after I and II steps of frying, the ratio $\alpha$-solanine to $\alpha$-chaconine was lower (1.0:2.0) than in unpeeled potatoes (1.0:2.3).

Keywords Red- and blue-fleshed potatoes - French fries processing $\cdot$ Glycoalkaloids $\cdot$ HPLC $\cdot$ Semi-products . Ready products

\section{Introduction}

Potatoes with traditional, light-flesh have been known since a long time-firstly eaten boiled, dried or baked, and then grilled or fried as fried snacks products. Next, apart from the light-flesh potatoes, coloured-fleshed varieties from South America were also available in the market [22]. Redand blue-fleshed potatoes are gaining in recognition, mostly thanks to antioxidant content having pro-healthy effect on the human organism [15]. These include the natural pigments-anthocyanins, especially the acylated derivatives [4]. Potato anthocyanins have been proved to hold much anti-illness and anti-ageing functionality [14]. The amount of antioxidants in coloured-fleshed potatoes is usually two or three times higher than in white-fleshed ones [2, 14].

The increasing popularity of coloured-fleshed varieties is also connected with their non-typical appearance and possibility of preparing colourful salads or attractive potato snacks. Coloured-fleshed potato crisps have already been available in the United States and some European countries, e.g. Germany, France and Italy [10]. It is quite likely that "coloured French fries" may soon appear in restaurants and shops.

Civilization progress in many countries has been accompanied by the constantly increasing consumption of fried potato snacks such as snacks, crisps and French fries. The 
French fries are especially popular due to their favourable organoleptic features and the fast and easy preparation to consumption at home $[16,36]$. It is quite probably that consumers, especially children and youth, looking for new snacks, might also pay attention in coloured French fries (red or blue). The fact that coloured-fleshed potatoes contain, abovementioned-anthocyanins [2, 4, 11, 15], snack products obtained from coloured-fleshed potatoes could be more willingly eaten up by consumers.

However, apart from pro-healthy components, potatoes also contain undesirable compounds, i.e. glycoalkaloids (TGA), which are potent poisons [5, 8-10]. The lethal dose of these components is $3-5 \mathrm{mg} \mathrm{kg}^{-1}$ body weight, with an effect similar to strychnine or arsenic $[9,12]$. The toxicity of TGA is associated with the synergistic interaction between two main components of TGA: $\alpha$-solanine and $\alpha$-chaconine $[8,16,19,23]$.

Glycoalkaloids occur both in potato tubers of traditional, light-flesh $[5,8,19,23]$ and in coloured-fleshed potatoes $[7,10,38]$. Both $\alpha$-solanine and $\alpha$-chaconine are triglycosylated derivatives of the same aglycone and solanidine but differ in the carbohydrate moiety $[8,35]$. In potatoes, $\alpha$-solanine constitutes about $40 \%$ of TGA and $\alpha$-chaconine $60 \%$, which is more toxic than $\alpha$-solanine, and hence, the ratio of these compounds is important $[8,9,20]$. The ratio of $\alpha$-solanine to $\alpha$-chaconine and total TGA content depend on the anatomical part of the potato plant and its variety [5, $8,20,23,26]$.

Glycoalkaloid content in potato tubers should not exceed $200 \mathrm{mg} \mathrm{kg}{ }^{-1}$ f.w., because this level is dangerous for the human health $[5,8,12,29]$, whereas the bitter taste of potato is clearly perceptible when amount of TGA in tuber is in the range of $14-15 \mathrm{mg}^{100 \mathrm{~g}^{-1}}$ [24]. The constant control of TGA content in potatoes intended for consumption should be carried on due to the confirmed toxicity of these components for human organism [13]. The largest amounts of TGA are present in the peel and immediately below the peel, about 1-1.5 mm [5, 8, 39]. And therefore the peeling process, used during their preparing for consumption, may remove from 20 to $80 \%$ of TGA from tubers [3, 25, $27,32,37]$. Subjecting the potatoes to thermal processing, e.g. cooking, baking, drying or frying, also enables us to remove the certain amounts of TGA, which can be differentiate dependency on the processing course $[8,25,27,31$, $32,38]$.

It is likely that coloured-fleshed potatoes (red- and blue-flesh) will be more commercially available, what can increase their popularity among consumers. Fried snacks, with or without peel, can be more often prepared of such potatoes. Coloured potato snacks may also become available in fast food restaurants, which will increase their total consumption. Therefore, taking into account the toxicity of TGA ( $\alpha$-solanine and $\alpha$-chaconine) contained in potatoes, it is necessary to control their amount in the coloured-fleshed varieties. It is essential to estimate the quantity of these components in coloured potato tubers, which remain in the flesh after the peeling, is rejected with the peel. And first of all, what quantity of TGA is present in fried products is obtained from coloured-fleshed potatoes. It also seems sensible to indicate the variety or varieties of potatoes that could be most suitable for French fries production.

The aim of this study was to determine the effect of different stages of French fries processing on the content of TGA ( $\alpha$-solanine and $\alpha$-chaconine) in the red- and blue-fleshed potatoes, in semi-products and ready-to-eat products.

\section{Materials and methods}

Raw material

The material taken for the study was consisted of four coloured potato varieties: two of red-fleshed (Herbie 26, Highland Burgundy Red) and two of blue-fleshed (Blue Congo, Vitelotte) from the growing seasons of 2009, 2010 and 2011. The potatoes grew in the experimental plots belonging to the testing station of The Central Institute for Supervising and Testing in Agriculture at Přerov nad Labem (the Czech Republic). The samples of potato tubers were harvested after reaching full maturity. Mechanically damaged, greened and sprouted potatoes were rejected after harvest. Selected tubers weighted more than $50 \mathrm{~g}$ were taken for the analyses. Each sample of potato varieties weighted $16 \mathrm{~kg}$.

\section{The method of French fries processing}

The research was carried out on tubers of red- and bluefleshed potato varieties. The potatoes of four varieties were used to prepare French fries. The coloured-fleshed potatoes met the requirements for French fries production, concerning the basic chemical composition of tubers, with particular emphasis on reducing sugars.

French fries were prepared by two-step frying method in rapeseed oil. In the study was used the rapeseed oil because it was characterized by a good thermal and oxidative stability during frying, and it has been generally used for the industrial preparation of fried food [21]. The tubers were washed and peeled by the use of potato peeler (Sirman model PP 4, Italy). The potato tubers were cut into strips sized $1 \times 1 \mathrm{~cm}, 6-7$ long and blanched in water at $75^{\circ} \mathrm{C}$ for $10 \mathrm{~min}$. After blanching, potato strips were dried on blotting paper. At the first stage of frying, the potato strips were fried in oil ( $3.5 \mathrm{~L}$ per $200 \mathrm{~g}$ of potato strips) at $175{ }^{\circ} \mathrm{C}$ for $1 \mathrm{~min}$. There was used $3.5 \mathrm{~L}$ of oil per $200 \mathrm{~g}$ of potato strips during frying of French fries-according to 
the methodology found in the articles of authors Lisińska et al. [18] and Tajner-Czopek et al. [38]. After cooling, the French fries were frozen in a freezer at $-18{ }^{\circ} \mathrm{C}$. At the second stage of frying, the French fries were fried in oil at $175{ }^{\circ} \mathrm{C}$ for $5 \min [16,18]$.

Sample preparation of coloured-fleshed potato

Glycoalkaloids (TGA) content was determined in the potato tubers of the examined coloured-fleshed varieties, in 1/unpeeled potatoes (raw material), 2/peeled potatoes, 3/peel, 4/potato strips, 5/potato strips after blanching, 6/ French fries after I step of frying and 7/French fries after II step of frying. The manner of sampling is presented in Fig. 1.

Unpeeled and peeled potatoes were cut into $1-\mathrm{cm}$ discs, while peel, potato strips and potato strips after blanching were cut into small pieces. All samples were freeze-dried in apparatus of Edwards Firm. French fries after I and II steps of frying were defatted before analysis. French fries were degreased with diethyl ether solvent in Büchi Extraction System B-811 apparatus. The process was carried out at $68{ }^{\circ} \mathrm{C}$ for $3.5 \mathrm{~h}$. All obtained dry material, after being

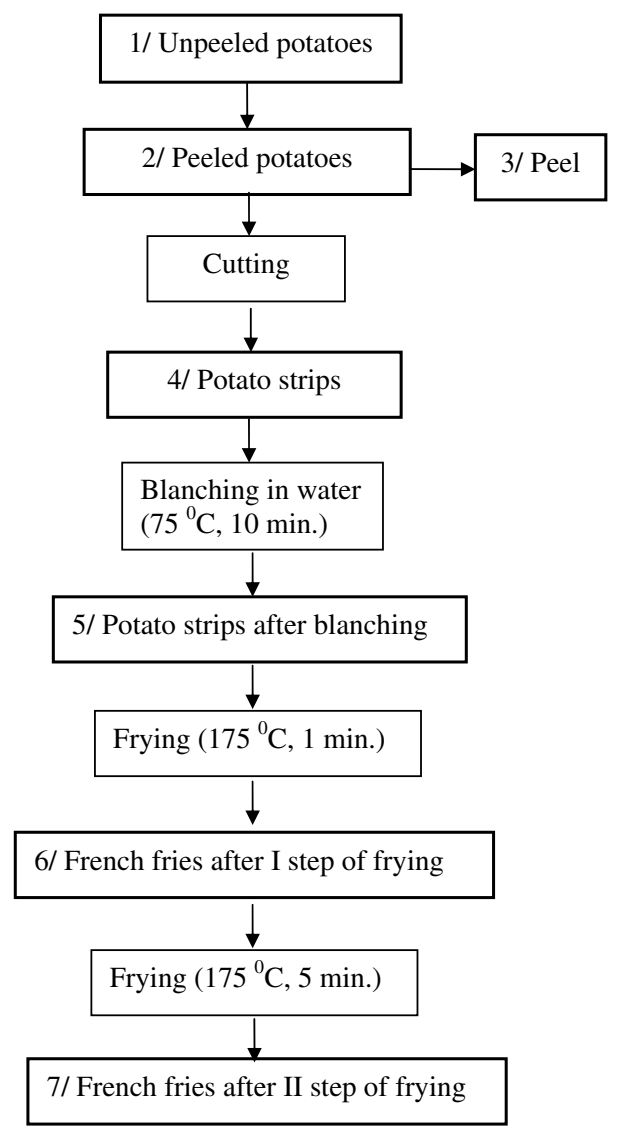

Fig. 1 The scheme of sample collection for TGA determination during French fries processing ground in an electric grinder (for $3 \mathrm{~min}$, each sample), became the material used to determine the contents of TGA ( $\alpha$-solanine and $\alpha$-chaconine).

\section{Determination of TGA content in samples prepared from coloured-fleshed potatoes}

Apparatus

A high-pressure liquid chromatography HPLC (ProStar) was used, made by the Varian Company (Walnut Creek, CA, USA), equipped with UV detector-310 type, analytical column Mikrosorb $\mathrm{NH}_{2}(25 \times 46 \mathrm{~cm}$ L.D. $)$ (Rainin Instrument, Woburn, MA, USA) and a computer system monitoring the chromatograph (Varian Chromatography System) [26, 34].

Conditions of the glycoalkaloid separation

As an eluent, a mixture of tetrahydrofuran, acetonitrile and redistilled water 50:20:30 $+\mathrm{KH}_{2} \mathrm{PO}_{4}\left(1.02 \mathrm{~g} \mathrm{~L}^{-1}\right.$ mixture $)$ was used. The process was carried out at a temperature of $35^{\circ} \mathrm{C}$, with the speed of flow of $2 \mathrm{~mL} \mathrm{~min}{ }^{-1}$ and the pressure of $112 \mathrm{~atm}$., applying the light wavelength of $208 \mathrm{~nm}$ $[26,34]$.

Sample preparation for the chromatograph analysis

The freeze-dried material $(1 \mathrm{~g})$ was homogenized with $4 \mathrm{~mL}$ redistilled water and $30 \mathrm{~mL}$ of methanol for $2 \mathrm{~min}$, followed by filtration. The filtration was carried out by using the filter paper and covered with a watch glass. The filtrate was brought to a final volume of $50 \mathrm{~mL}$ with methanol. A $5 \mathrm{~mL}$ aliquot of the extract was cleaned up on the SPE column (Bond Elut C18; $500 \mathrm{mg} ; 6.0 \mathrm{~mL}$ ) (Varian, USA) with the $0.9 \mathrm{~mL} \mathrm{~min}{ }^{-1}$ speed flow. TGAs were rinsed using $5 \mathrm{~mL}$ of methanol and evaporated to dryness in vacuum at a temperature of $50{ }^{\circ} \mathrm{C}$. The residue formed was dissolved in $1 \mathrm{~mL}$ of THF:ACN: $\mathrm{H}_{2} \mathrm{O}-50: 20: 30$. Before application onto the column, the sample was cleaned up by using filters of $0.45 \mu \mathrm{m}$. The volume of the injection was $10 \mu \mathrm{L}$.

Standard solutions $\left(1 \mathrm{mg} \mathrm{mL}^{-1}\right)$ were prepared by dissolving $10 \mathrm{mg}$ of $\alpha$-solanine and $\alpha$-chaconine (SigmaAldrich, Germany) in $10 \mathrm{~mL}$ of methanol. Standard solution was dissolved to obtain samples containing from 1 to $50 \mu \mathrm{g} \mathrm{mL}^{-1}$ both $\alpha$-solanine and $\alpha$-chaconine. $10 \mu \mathrm{L}$ of solution was injected on the column [26, 34].

Analytical methods

The dry matter of all samples was determined by the reduced weight after drying at $105^{\circ} \mathrm{C}$ until constant weight 
[1]. The quantities of $\alpha$-solanine and $\alpha$-chaconine (total TGA) were determined by the method of Saito et al. [34] and Pęksa et al. [26]. All experiments were conducted in three technological replications (in 2009, 2010 and 2011 years of the investigation), and the present results show the average values obtained in the study.

\section{Statistical analysis}

The data were analysed statistically using Statistica 10.0 software. For comparison, the results obtained were analysed using one-way analysis of variance with the application of Duncan's test $(P \leq 0.05)$. One-way analysis of variance was used for determining the significance of the influence of stage of French fries processing on the contents of total TGA ( $\alpha$-solanine and $\alpha$-chaconine) in studied samples. Standard deviations and LSD (least significant differences) were estimated by means of Statistica 10.0.

\section{Results and discussion}

\section{Raw material (coloured-fleshed potatoes)}

The dry matter of all studied coloured-fleshed potato varie-

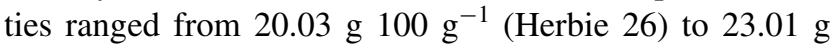
$100 \mathrm{~g}^{-1}$ (Vitelotte) and the starch content from $14.60 \mathrm{~g}$

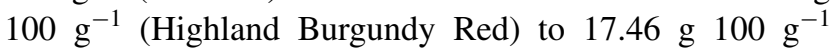

(Vitelotte). The content of reducing sugar in all potato varieties ranged from $0.15 \mathrm{~g} 100 \mathrm{~g} \mathrm{~g}^{-1}$ (Vitelotte) to $0.24 \mathrm{~g}$ $100 \mathrm{~g}^{-1}$ (Blue Congo) (Table 1). The morphology and the precisely definite chemical composition (dry matter, starch and first of all reducing sugar content) are the most important features of potatoes used for industry processing [16, 17]. It is important that potato tubers selected for French

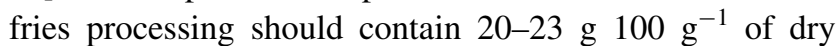

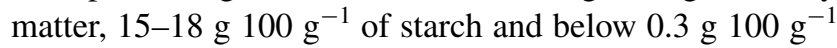
of reducing sugar [17]. All researched coloured-fleshed potatoes met the requirements for the raw material destined for French fries processing, in respect of dry matter, starch and (especially-first of all) the reducing sugar content (Table 1).

Glycoalkaloid content in unpeeled coloured-fleshed potatoes, peeled potatoes and peel

In this study, there was stated that TGA content in coloured-fleshed potatoes (red- and blue-fleshed) did not show significant differences among the years of the investigation. However, there was found statistical difference dependency on the potato varieties (Table 2). The amount of TGA accumulated in the tubers depended mainly on their genotype [33]. The highest content of TGA was found in Blue Congo variety $\left(6.11,6.06\right.$ and $6.10 \mathrm{mg} 100 \mathrm{~g}^{-1}$ f.w.), respectively, and the lowest in Vitelotte variety (4.05, 4.10 and $4.09 \mathrm{mg}$ $100 \mathrm{~g}^{-1}$ f.w.), independently of the year of study (Table 2).
Table 1 Dry matter, starch and reducing sugar content $\left(\mathrm{g} 100 \mathrm{~g}^{-1}\right)$ in potato tubers of four coloured-fleshed potato varieties

Values are given as mean $\pm \mathrm{SD}$ (standard deviation), $n=9$

\begin{tabular}{|c|c|c|c|}
\hline Potato variety & Dry matter $\left(\mathrm{g} 100 \mathrm{~g}^{-1}\right)$ & 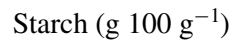 & 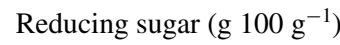 \\
\hline \multicolumn{4}{|l|}{ Red-fleshed potatoes } \\
\hline Herbie 26 & $20.03 \pm 0.20$ & $14.96 \pm 0.16$ & $0.17 \pm 0.09$ \\
\hline $\begin{array}{l}\text { Highland Burgundy Red } \\
\text { Blue-fleshed potatoes }\end{array}$ & $20.92 \pm 0.21$ & $14.60 \pm 0.10$ & $0.21 \pm 0.10$ \\
\hline Blue Congo & $21.31 \pm 0.24$ & $15.67 \pm 0.13$ & $0.24 \pm 0.12$ \\
\hline Vitelotte & $23.01 \pm 0.17$ & $17.46 \pm 0.15$ & $0.15 \pm 0.10$ \\
\hline
\end{tabular}

Table 2 The content of total glycoalkaloids (g $100 \mathrm{~g}^{-1}$ f.w.) in four coloured-fleshed potato varieties (from 3 years)

\begin{tabular}{|c|c|c|c|}
\hline Potato variety & 2009 & $\begin{array}{l}\text { Year of the investigation } 2010 \\
\text { glycoalkaloids (mg } 100 \mathrm{~g}^{-1} \text { f.w.) }\end{array}$ & 2011 \\
\hline \multicolumn{4}{|l|}{ Red-fleshed potatoes } \\
\hline Herbie 26 & $5.40 \pm 0.04^{\mathrm{c}, \mathrm{A}}$ & $5.33 \pm 0.05^{\mathrm{c}, \mathrm{A}}$ & $5.41 \pm 0.03^{\mathrm{c}, \mathrm{A}}$ \\
\hline Highland Burgundy Red & $4.40 \pm 0.02^{\mathrm{b}, \mathrm{A}}$ & $4.45 \pm 0.03^{\mathrm{b}, \mathrm{A}}$ & $4.44 \pm 0.02^{\mathrm{b}, \mathrm{A}}$ \\
\hline \multicolumn{4}{|l|}{ Blue-fleshed potatoes } \\
\hline Blue Congo & $6.11 \pm 0.03^{\mathrm{d}, \mathrm{A}}$ & $6.06 \pm 0.02^{\mathrm{d}, \mathrm{A}}$ & $6.10 \pm 0.05^{\mathrm{A}}$ \\
\hline Vitelotte & $4.05 \pm 0.02^{\mathrm{a}, \mathrm{A}}$ & $4.10 \pm 0.03^{\mathrm{a}, \mathrm{A}}$ & $4.09 \pm 0.03^{\mathrm{A}}$ \\
\hline
\end{tabular}

Values are given as mean $\pm \mathrm{SD}$ (standard deviation), $n=9$

f.w. fresh weight basis

a,b,c,d Difference superscripts within columns indicate significant differences (Duncan's test, $P \leq 0.05$ )

A Superscripts in raw indicate non-significant differences (Duncan's test, $P \leq 0.05$ ) 
Table 3 Content of glycoalkaloids (mg $100 \mathrm{~g}^{-1}$ f.w.) in un-peeled potatoes, peeled potatoes and peel obtained from red- and blue-fleshed potatoes

\begin{tabular}{|c|c|c|c|}
\hline Potato variety & Unpeeled potatoes & $\begin{array}{l}\text { Peeled potatoes Glycoalkaloids } \\
\text { (mg } 100 \mathrm{~g}^{-1} \text { f.w.) }\end{array}$ & Peel \\
\hline \multicolumn{4}{|l|}{ Red-fleshed potatoes } \\
\hline Herbie 26 & $5.38 \pm 0.05^{\mathrm{c}}$ & $2.85 \pm 0.01^{\mathrm{c}}$ & $17.62 \pm 0.22^{\mathrm{c}}$ \\
\hline Highland Burgundy Red & $4.43 \pm 0.03^{\mathrm{b}}$ & $2.19 \pm 0.02^{\mathrm{b}}$ & $20.10 \pm 0.16^{\mathrm{d}}$ \\
\hline \multicolumn{4}{|l|}{ Blue-fleshed potatoes } \\
\hline Blue Congo & $6.09 \pm 0.03^{\mathrm{d}}$ & $3.13 \pm 0.03^{\mathrm{d}}$ & $14.20 \pm 0.12^{\mathrm{a}}$ \\
\hline Vitelotte & $4.08 \pm 0.03^{\mathrm{a}}$ & $1.81 \pm 0.02^{\mathrm{a}}$ & $15.61 \pm 0.31^{\mathrm{b}}$ \\
\hline Mean & 4.99 & 2.49 & 16.88 \\
\hline $\mathrm{LSD}_{\text {mean of TGA content }}$ & 0.13 & 0.25 & 1.2 \\
\hline
\end{tabular}

Values are given as mean $\pm \mathrm{SD}$ (standard deviation), $n=9$

f.w. fresh weight basis

$L S D$ least significant differences

a,b,c,d Differences superscripts within columns indicate significant differences (Duncan's test, $P \leq 0.05$ )

Various coloured-fleshed (red- and blue-fleshed) potato varieties that could be potentially used in the production of French fries are still little researched with regard to their TGA content. Therefore, it is significant to determine the quantity of TGA in unpeeled tubers, flesh and peel, and the more so traditional French fries are produced from peeled potatoes.

On the ground of findings, it was stated that content of TGA in studied coloured-fleshed potato varieties ranged from 4.08 to $6.09 \mathrm{mg} 100 \mathrm{~g}^{-1}$ f. w., in peeled potatoes

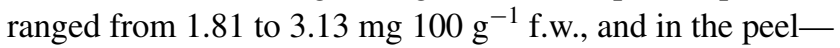

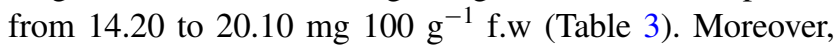
it was found that blue-fleshed potatoes of Blue Congo variety were characterized by the highest content of TGA. The amount of TGA in these potatoes was about $33 \%$ higher compared with the Vitelotte variety, about $27 \%$ higher than in the Highland Burgundy Red variety and by approximately $12 \%$ higher than in the Herbie 26 variety. Blue Congo potato variety was also characterized by the highest content of the examined compound in the peeled tubers (on average about $27 \%$ more) and the lowest amount of TGA in the peel (on average about $18 \%$ less) compared with other varieties. Presumably, a large amount of TGA in Blue Congo variety was in the flesh and little in the peel, and therefore, very little of studied compound was removed during the peeling. It was stated that Blue Congo potato varieties should not be recommended for the production of French fries.

It was also stated that unpeeled and peeled potatoes of blue-fleshed Vitelotte variety were characterized by the lowest amount of TGA. Peels obtained from these potatoes contained relatively low amount $15.61 \mathrm{mg} 100 \mathrm{~g}^{-1}$ f.w of TGA (Table 3). Moreover, it was found that Highland Burgundy Red (red-fleshed potatoes), which were characterized by a relatively low amount of TGA in the unpeeled and peeled potatoes, contained the highest quantity of the studied compound in the peel, as compared with other varieties-20.10 mg $100 \mathrm{~g}^{-1}$ f.w. Probably, Highland Burgundy Red potato variety accumulates the highest amount of TGA in the peel; therefore, much less TGA content was in the flesh after the peeling. It was stated that Highland Burgundy Red potato varieties should be recommended as useful raw material for the French fries production, as well Vitelotte variety.

Ieri et al. [10] reported that TGA content in four coloured-fleshed potato varieties ranged from 6.6 to $13.9 \mathrm{mg}$ $100 \mathrm{~g}^{-1}$ f.w., in peeled potatoes from 0.94 to $1.15 \mathrm{mg}$ $100 \mathrm{~g}^{-1}$ f.w. and in the peel from 42.1 to $85.6 \mathrm{mg} 100 \mathrm{~g}^{-1}$ f.w. Friedman and Levin [7] reported that in eight potato varieties, the amount of TGA ranged from 0.8 to $18.7 \mathrm{mg}$ $100 \mathrm{~g}^{-1}$ f.w, in peeled potatoes ranged from 0.13 to $14.80 \mathrm{mg} 100 \mathrm{~g}^{-1}$ f.w. and in the peel-from 1.24 to $54.30 \mathrm{mg} 100 \mathrm{~g}^{-1}$ f.w. Rytel et al. [33] showed/noticed that the amount of TGA in a peel obtained from colouredfleshed potato varieties ranged from $15.33 \mathrm{mg} 100 \mathrm{~g}^{-1}$ f.w. to $24.45 \mathrm{mg} 100 \mathrm{~g}^{-1}$ f.w. Nema et al. [23] reported that TGA content in frozen peels of different edible varieties ranged from 6.5 to $12.1 \mathrm{mg} 100 \mathrm{~g}^{-1}$ f.w. Many authors, Friedman and Dao [6], Wünsch and Munzert [39], Friedman [5], and Friedman and Levin [7], reported that most TGA in the tuber are accumulated in the peel, especially in the area of eyes, whereas the distribution of TGA in a tuber differs among varieties. Some researchers, Wünsch and Munzert [39], Friedman and McDonald [8], Pęksa et al. [26], Friedman [8], Tajner-Czopek et al. [37] and Ostry et al. [25], think that there may occur significant differences in TGA content among of the same varieties. Ieri et al. [10] also showed significant difference in TGA between bluefleshed tubers of the same varieties. 
From the results, it was stated that peels obtained from Highland Burgundy Red potato variety contained about 4.5 times and from Vitelotte about 3.8 more TGA, than unpeeled potatoes. The peels obtained from Herbie 26 contained about 3.3 times more and derived from Blue Congo variety about 2.3 times more of TGA content in comparison with raw material. The peels from four potato varieties had on average almost 3.5 times more TGA content compared with unpeeled potatoes (Table 3).

Friedman and Levin [7] reported that in peels obtained from eight potato varieties, TGA content was 1.5-11 times higher compared with the raw material, while Ieri et al. [10] reported that in peels of four coloured-fleshed potato varieties, the TGA concentration is on average six times higher in comparison with unpeeled potatoes.

\section{The content of TGA ( $\alpha$-solanine and $\alpha$-chaconine) in processed of coloured-fleshed potatoes}

\section{TGA content after peeling}

Based on the results presented in Figs. 2 and 3, it was stated that TGA content in the examined red- and blue-fleshed potato varieties did not exceed $26 \mathrm{mg} 100 \mathrm{~g}^{-1}$ d.w., and the quantity of studied component distinctly decreased during the consecutive stages of French fries preparation. The first stage-peeling-significantly decreased the total amount of TGA ( $\alpha$-solanine and $\alpha$-chaconine) in the colouredfleshed potatoes by about $50 \%$ on average, compared with a raw material (Figs. 2, 3). Peeling the blue-fleshed potatoes of Vitelotte variety, with the lowest TGA content in unpeeled tubers, resulted in the greatest loss of $\alpha$-solanine and $\alpha$-chaconine sum (by about $55 \%$ ), among other examined varieties (Figs. 2,3), whereas peeling potatoes of Blue Congo variety with the highest TGA content in the raw material resulted the lowest decrease in TGA by $45 \%$ (Figs. 2, 3).

Jansen and Flamme [11] reported that peeling colouredfleshed varieties influenced on almost $50 \%$ decrease in TGA content compared with raw material, whereas Ieri et al. [10] reported that peeled blue-fleshed potato of Shetland Black variety decreased about $64 \%$ amount of TGA compared with unpeeled tubers. Rytel et al. [33] showed that peeling of coloured-fleshed potato decreased in TGA content by about $70 \%$. Rytel et al. [32] and Pęksa et al. [27] observed that peeling traditional light-fleshed potatoes decreased in TGA content by about 20-35\%, whereas Tajner-Czopek et al. [37] showed that peeling the potato tubers of three light-fleshed varieties decreased in TGA content by $58 \%$. The amount of removed TGA depended on the way of peeling, including the thickness of peel and the layer of flesh removed with the peel $[3,8,38]$.

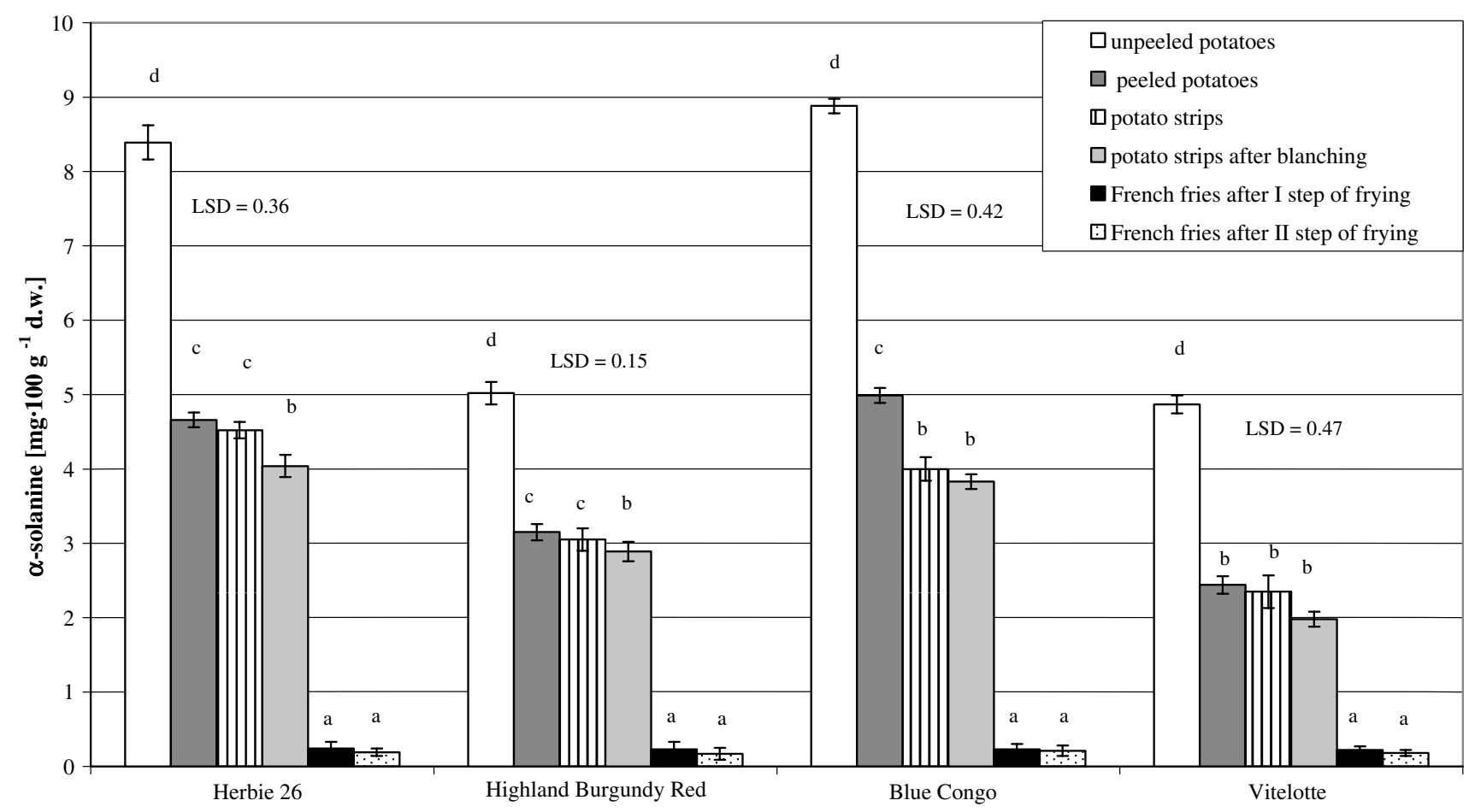

Fig. 2 Content of $\alpha$-solanine ( $\mathrm{mg} \mathrm{kg}^{-1}$ d.w.) in raw tubers and processed on French fries red- and blue-fleshed potatoes of four variegiven as mean $n=9 . L S D$ least significant differences (Duncan's test, ties. Error bars represent the standard deviation $( \pm \mathrm{SD})$. Values are 


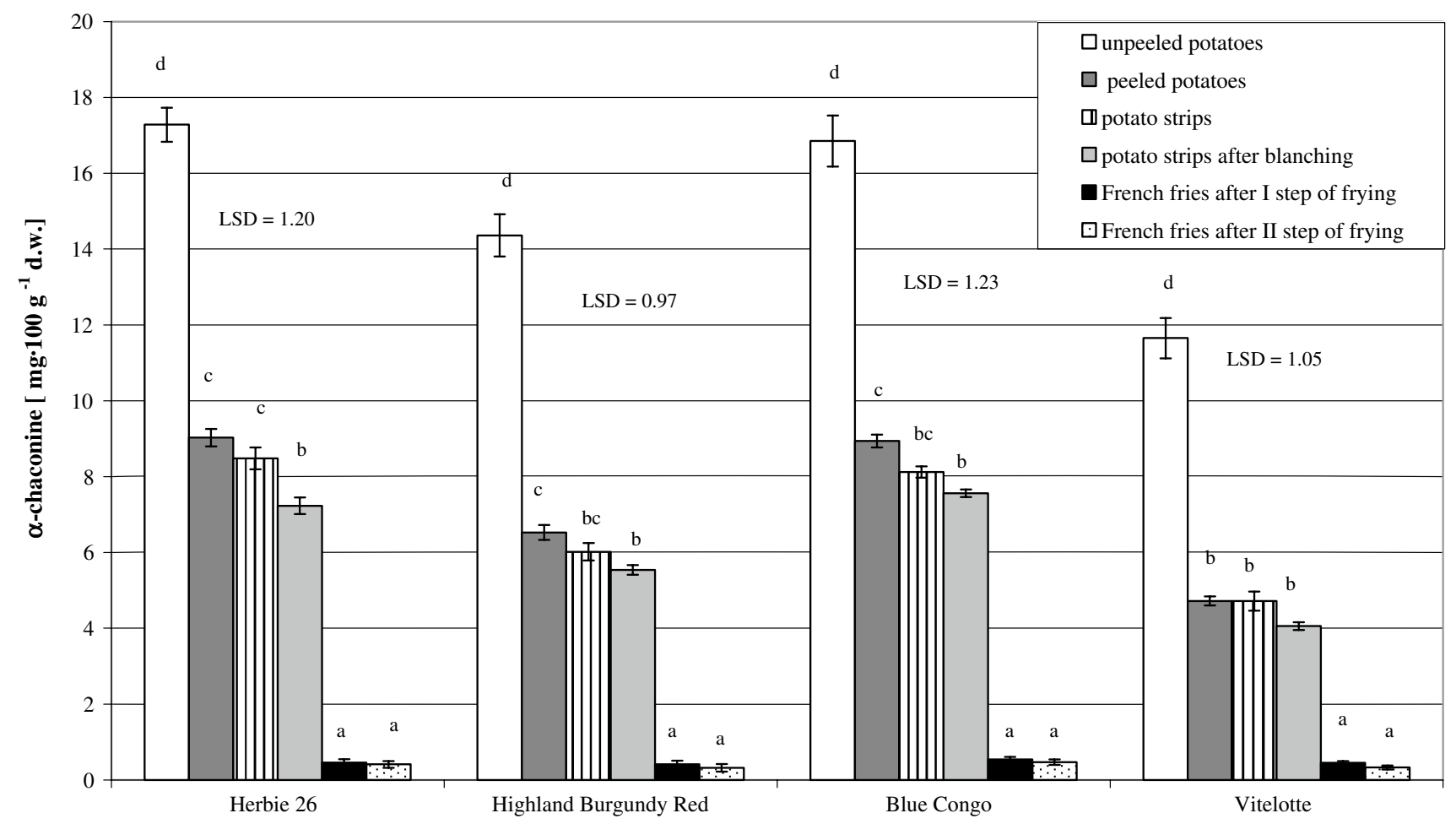

Fig. 3 Content of $\alpha$-chaconine ( $\mathrm{mg} \mathrm{kg}^{-1}$ d.w.) in raw tubers and processed on French fries red-and blue-fleshed potatoes of four varieties. Error bars represent the standard deviation $( \pm \mathrm{SD})$. Values are given as mean $n=9$. $L S D$ least significant differences (Duncan's test, $P \leq 0.05) ; d . w$ dry weight

in red- and blue-fleshed potatoes decreased on average by $58 \%$ than in raw material (Figs. 2, 3). Relatively, the greatest loss of $\alpha$-solanine content, by about $59 \%$ (Fig. 2), and $\alpha$-chaconine content, by about $65 \%$ (Fig. 3), was induced after blanching the potato strips of Vitelotte variety, compared with raw material. The lowest decrease in $\alpha$-solanine content, by about $42 \%$, was stated after blanching potato strips of Highland Burgundy Red variety (Fig. 2) and $\alpha$-chaconine content, by about $55 \%$, in potato strips of Blue Congo variety (Fig. 3), compared with unpeeled potatoes.

Rytel et al. [32] reported that after the first and second stage of blanching the potato strips obtained from lightfleshed potatoes, TGA content decreased by about 69 and $74 \%$ than in raw material. Rytel [31] observed that after blanching of light-fleshed potato strips, the amount of TGA decreased by $63 \%$ than in raw material. While Cieślik [3] noticed that blanching process decreased the quantity of TGA by about 40-50\% compared with raw material. The same author also observed that cooking markedly decreased the TGA content in potatoes, especially when they are cooked in disintegrated form (dice, strips). TajnerCzopek et al. [37] observed that dependency on variety, the amount of TGA decreased on average by about $80 \%$ compared with raw material, after cooking of potatoes. that after blanching, $\alpha$-solanine and $\alpha$-chaconine content 
Table 4 Ratio of $\alpha$-solanine to $\alpha$-chaconine concentration of raw and processed French fries of coloured-fleshed potato varieties (mean of four coloured-fleshed potato varieties)

\begin{tabular}{lcclccc}
\hline & $\begin{array}{l}\text { Raw material } \\
\text { unpeeled potatoes }\end{array}$ & Peeled potatoes & $\begin{array}{l}\text { Processed potato } \\
\text { strips }\end{array}$ & $\begin{array}{l}\text { Potato strips after } \\
\text { blanching }\end{array}$ & $\begin{array}{l}\text { French fries after I } \\
\text { step of frying }\end{array}$ & $\begin{array}{l}\text { French fries after II } \\
\text { step of frying }\end{array}$ \\
\hline $\begin{array}{c}\text { Ratio } \alpha \text {-solanine } \\
\text { to } \alpha \text {-chaconine } \\
\text { (mean value of } \\
\text { four coloured- } \\
\text { fleshed potatoes) }\end{array}$ & $1.0: 2.3$ & $1.0: 1.9$ & $1.0: 2.0$ & $1.0: 1.9$ & $1.0: 2.0$ \\
\hline
\end{tabular}

\section{TGA content in French fries after frying}

In French fries production, blanched potato strips are dried and fried in oil $[16,18,36]$. Frying process gives fried potatoes the organoleptic qualities that are attractive to consumers. Frying may also have a positive effect on reduction the TGA content in the ready products $[3,5,8,32,38]$.

On the ground of findings, it was stated that frying process had significantly decreased in TGA content, by about $97 \%$, after I step of frying, and by about $97.5 \%$, after II step of frying, compared with raw material. Therefore, there was only $3 \%$ of the initial quantity of TGA in the semi-products (after I step of frying) and $2.5 \%$ in ready-toeat French fries (Figs. 2, 3).

Rytel et al. [32] noticed that in ready French fries (after the II step of frying), made from traditional light-fleshed varieties (Santana and Innovator), there remained 3-8 \% of initial amount of TGA. However, Pęksa et al. [27] observed that in crisps, made from Karlena and Saturna varieties, there was only $1-2 \%$ of the initial TGA content found in the raw material. Friedman and McDonald [8] noticed that a fryinginduced TGA decrease (frying at $170-180{ }^{\circ} \mathrm{C}$ ) is partly associated with washing the TGA out from frying product and partly with its decomposition influenced by hot oil.

Changes in the ratio of $\alpha$-solanine to $\alpha$-chaconine

In Table 4 was given the ratio of $\alpha$-solanine to $\alpha$-chaconine concentration of raw and processed French fries of coloured-fleshed potato varieties (mean of four colouredfleshed potato varieties). It was stated that ratio of $\alpha$-solanine to $\alpha$-chaconine changed (decreased) in studied samples during French fries processing compared with raw material. In conducted studies, it was stated that ratio of $\alpha$-solanine to $\alpha$-chaconine in unpeeled coloured-fleshed potatoes was 1.0:2.3 (Table 4).

The ratio of $\alpha$-solanine to $\alpha$-chaconine varies between varieties, although $\alpha$-chaconine usually occurs in distinctly higher concentration than $\alpha$-solanine $[6,8,16,23,30$, 37]. The scientific literature most frequently has provided data on the ratio of $\alpha$-solanine to $\alpha$-chaconine in lightfleshed varieties. Pęksa et al. [27] observed the ratio in light-fleshed varieties ranged from 1.0:2.4 to 1.0:3.7, while Friedman and Levin [7] claimed that ratio of $\alpha$-chaconine to $\alpha$-solanine ranged from 1.20 to 2.60. Tajner-Czopek et al. [37] reported that in Bard, Lord and Denar varieties, the ratio of these compounds was from 1.0:1.9 to 1.0:2.5.

Only a few authors have determined the TGA content in coloured-fleshed potato varieties. Rodrigez-Saona et al. [28] showed that ratio of $\alpha$-chaconine to $\alpha$-solanine in 35 red-fleshed potato breeding clones was on average 1.0:2.4. Ieri et al. [10] in their study observed that ratio of $\alpha$-chaconine to $\alpha$-solanine in intensively blue-fleshed potato variety (Vitelotte Noire) was 1.0:2.7, whereas Tajner-Czopek et al. [38] noticed that ratio of these compounds in blue-fleshed potatoes was 1.0:1.8, while in redfleshed potatoes, the ratio was 1.0:2.2. Rytel et al. [33] showed that ratio of $\alpha$-solanine to $\alpha$-chaconine in red- and blue-fleshed potatoes was ranged from 1.0:1.8 to 1.0:2.1, respectively. The content of $\alpha$-solanine is about two times more than $\alpha$-chaconine [33].

On the ground of findings, it was stated that ratio of $\alpha$-solanine to $\alpha$-chaconine decreased after peeling the coloured-fleshed potatoes, compared with the raw material, and was 1.0:1.9 as an average for varieties. The ratio of $\alpha$-solanine to $\alpha$-chaconine changed in favour of $\alpha$-solanine. However, the ratio of both compounds was 1.0:2.0 in peels obtained after peeling the studied potato varieties (Table 4).

In French fries production, raw material is subjected to initial processing, i.e. washing, peeling, cutting, thermally processed in blanching and frying [16, 37]. Both peeling and thermal processes had an effect on the TGA content and the ratio of $\alpha$-solanine to $\alpha$-chaconine [3, 5, 8, 27, 38]. It was stated that cutting, blanching and frying French fries prepared from red- and blue-fleshed varieties had an effect on their $\alpha$-solanine to $\alpha$-chaconine ratio, which on average changed from 1.0:1.9 to 1.0:2.0 (Table 4). Moreover, it was stated that blanching process had an marked effect on reducing the $\alpha$-solanine to $\alpha$-chaconine ratio (1.0:1.9) compared with the unpeeled potatoes (1.0:2.3), which was associated with amount of TGA rinsed during the blanching. In French fries after I and II steps of frying, the ratio $\alpha$-solanine to $\alpha$-chaconine was lower than in unpeeled potatoes (Table 4). 
Rytel et al. [32] observed that the ratio of $\alpha$-solanine to $\alpha$-chaconine in the ready French fries, obtained from traditional light-fleshed potatoes, was 1.0:1.0 (Innovator variety) and 1.0:1.3 (Santana variety). Above-mentioned researchers also noticed that during the entire French fries processing, the ratio of both fractions of TGA decreased from 1.0:2.4 to 1.0:1.1, whereas Pęksa et al. [27] observed that the ratio of $\alpha$-solanine to $\alpha$-chaconine was on stable level of 1.0:2.5 during all the stages of production of potato crisps. These authors also observed that after peeling, slicing and washing out in water, $\alpha$-solanine content decreased more than $\alpha$-chaconine.

\section{Conclusions}

It was stated that during the processing of French fries prepared from coloured-flesh potato varieties significantly decreased the content of TGA ( $\alpha$-solanine and $\alpha$-chaconine) in the samples obtained at different stages of the process compared with the raw material. Potatoes with blue-fleshed of Vitelotte variety and red-fleshed of Highland Burgundy Red variety can be used to French fries processing due to their low content of TGA (in unpeeled and peeled potatoes). However, Blue Congo variety with bluefleshed should not be applied to French fries processing, because of high TGA content in raw material and first of all in peeled potatoes flesh. The peeling process of colouredfleshed potatoes decreased in TGA content ( $\alpha$-solanine and $\alpha$-chaconine) on average by about $50 \%$, cutting process on average by about $53 \%$, whereas blanching on average by about $58 \%$ compared with the raw material. The highest decrease in TGA content was caused by frying process. The mean values were about $97.5 \%$ in ready-to-eat French fries (after II stage of frying). In French fries after I and II steps of frying, the ratio of $\alpha$-solanine to $\alpha$-chaconine was lower (1.0:2.0) than in unpeeled potatoes (1.0:2.3).

\section{Conflict of interest None.}

Compliance with Ethics Requirements This article does not contain any studies with human or animal subjects.

Open Access This article is distributed under the terms of the Creative Commons Attribution License which permits any use, distribution, and reproduction in any medium, provided the original author(s) and the source are credited.

\section{References}

1. AOAC (1995) Official methods of analytical chemist. Association of Official Analytical Chemist 5-th ed. Washington DC

2. Brown CR (2005) Antioxidant in potato. Am J Potato Res 82:163-172
3. Cieślik E (1995) The effect of cooking processes on glycoalkaloids content in potato tubers. Zesz Nauk AR w Krakowie 342:15-22 (in Polish)

4. Eichhorn S, Winterhalter P (2005) Anthocyanins from pigmented potato (Solanum tuberosum L.) cultivars. Food Res Int 38:943-948

5. Friedman M (2006) Potato glycoalkaloids and metabolites: role in the plant and in the diet. J Agric Food Chem 54:8655-8681

6. Friedman M, Dao L (1992) Distribution of glycoalkaloids in potato plants and commercial potato products. J Agric Food Chem 40:419-423

7. Friedman M, Levin CE (2009) In: Singh J, Kaur L (eds) Advances in potato chemistry and technology. Elsevier-Academic Press, USA

8. Friedman M, McDonald G (1997) Potato glycoalkaloids: chemistry, analysis, safety and plant physiology. Crit Rev Plant Sci 16:55-132

9. Haase NU (2010) Glycoalkaloid concentration in potato tubers related to storage and consumer offer. Potato Res 53:297-307

10. Ieri F, Innocenti M, Andrenalli L, Vecchio V, Mulinacci N (2011) Rapid HPLC/DAD/MS method to determine phenolic acids, glycoalkaloids and anthocyanins in 13 pigmented potatoes (Solanum tuberosum L.) and correlations with variety and geographical origin. Food Chem 125:750-759

11. Jansen G, Flamme W (2006) Coloured potatoes (Solanum tuberosum L.): anthocyanin content and tuber quality. Genetic Resour Crop Evol 53:1321-1331

12. JECFA (1992) Evaluation of Certain Food Additives and Naturally Occurring Toxicants. Thirty-ninth report of the Joint FAO/ WHO Expert Committee on Food Additives. WHO Technical Report Series, Geneva, 828: 31-33

13. Knuthsen P, Jensen U, Schmidt B, Larsen IK (2009) Glycoalkaloids in potatoes: content of glycoalkaloids in potatoes for consumption. J Food Compos Anal 22:577-581

14. Lachman J, Hamouz K (2005) Red and purple coloured potatoes as a significant antioxidant source in human nutrition: a review. Plant Soil Environ 51:477-482

15. Lachman J, Hamouz K, Šulc M, Orsák M, Pivec V, Hejtmánková A, Dvořak P, Čepl J (2009) Cultivar differences of total anthocyanins and anthocyanidins in red and purple-fleshed potatoes and their relation to antioxidant activity. Food Chem 114:836-843

16. Lisińska G, Leszczyński W (1989) Potato science and technology. Elsevier Applied Science, London

17. Lisińska G, Pęksa A, Kita A, Rytel E, Tajner-Czopek (2009) The quality of potato for processing and consumption. In N. Yee, W. Bussel (Eds.) Food Potato IV, 3, Special Issue 2: 99-104

18. Lisińska G, Tajner-Czopek A, Kalum L (2007) The effects of enzymes on fat content and texture of French fries. Food Chem 102:1055-1060

19. Mäder J, Rawel H, Kroh LW (2009) Composition of phenolic compounds and glycoalkaloids $\alpha$-solanine and $\alpha$-chaconine during commercial potato processing. J Agric Food Chem 57:6292-6297

20. Maga JA (1980) Potato glycoalkaloids and related compounds as potato quality factors. Am Potato J 61:123-139

21. Matthäus B (2006) Utilization of high-oleic rapeseed oil for deep-fat frying of French fries compared to other commonly used edible oils. Eur J Lipid Sci Technol 108:200-211

22. Mulinacci N, Ieri F, Giaccherini C, Innocenti M, Andrenelli L, Canova J, Saracchi M, Casiraghi MC (2008) Effect of cooking on the anthocyanins, phenolic acids, glycoalkaloids, and resistant starch content in two pigmented cultivars of Solanum tuberosum L. J Agric Food Chem 56:11830-11837

23. Nema PK, Ramayya N, Duncan E, Niranjan K (2008) Review: potato glycoalkaloids: formation and strategies for mitigation. $\mathrm{J}$ Sci Food Agic 88:1869-1881 
24. Osman SF (1983) Potato glycoalkaloids. J Agric Food Chem 11:235-247

25. Ostry V, Ruprich J, Skarkova J (2010) Glycoalkaloids in potato tubers: the effect of peeling and cooking in salted water. Acta Aliment 39:130-135

26. Pęksa A, Gołubowska G, Rytel E, Lisińska G, Aniołowski K (2002) Influence of harvest date on glycoalkaloids contents of three potato varieties. Food Chem 78:313-317

27. Pęksa A, Gołubowska G, Rytel E, Lisińska G, Aniołowski K (2006) Changes of glycoalkaloids and nitrate contents in potatoes during chip processing. Food Chem 97:151-156

28. Rodriguez-Saona L, Wrolstad RE, Pereira C (1999) Glycoalkaloid content and anthocyanin stability to alkaline treatment of red-fleshed potato extracts. J Food Sci 64:445-455

29. Ruprich J, Rehurkova I, Boon PE, Svensson K, Moussavian S, Van der Voet H, Bosgra S, Van Klaveren JD, Busk L (2009) Probabilistic modeling of exposure doses and implications for health risk characterization: glycoalkaloids from potatoes. Food Chem Toxicol 47:2899-2905

30. Rytel E (2012) Changes in glycoalkaloid and nitrate content in potato during dehydrated dice processing. Food Control 25:349-354

31. Rytel E (2012) The effect of industrial potato processing on the concentrations of glycoalkaloids and nitrates in potato granules. Food Control 28:380-384
32. Rytel E, Gołubowska G, Lisińska G, Pęksa A, Aniołowski K (2005) Changes in glycoalkaloids and nitrate contents in potatoes during French fries processing. J Sci Food Agric 85:879-882

33. Rytel E, Tajner-Czopek A, Aniołowska M, Hamouz K (2013) The influence of dehydrated potatoes processing on the glycoalkaloids content in coloured-fleshed potato. Food Chem 141:2495-2500

34. Saito K, Horie M, Hoshino Y, Nose N (1990) High performance liquid chromatographic determination of glycoalkaloids in potato products. J Chromat 508:141-147

35. Stanker LH, Kampos-Holtzapple C, Friedman M (1994) Development and characterization of monoclonal antibodies that differentiate between potato and tomato glycoalkaloids and aglycons. $\mathrm{J}$ Agric Food Chem 42:2360-2366

36. Tajner-Czopek A, Figiel A, Carbonell-Barrachina A (2008) Effects of potato strip size and pre-drying method on French fries quality. Eur Food Res Technol 227:757-766

37. Tajner-Czopek A, Jarych-Szyszka M, Lisińska G (2008) Changes in glycoalkaloids content of potatoes destined for consumption. Food Chem 106:706-711

38. Tajner-Czopek A, Rytel E, Kita A, Pęksa A, Hamouz K (2012) The influence of thermal process of coloured potatoes on the content of glycoalkaloids in the potato products. Food Chem 133:1117-1122

39. Wünsch A, Munzert M (1994) Effect of storage and cultivar on the distribution of glycoalkaloids in potato tuber. Potato Res 37:3-10 